\title{
EGY VIDÉKI SZARVASMARHATELEP EMBERI ERŐFORRÁSÁNAK VIZSGÁLATA
}

\author{
Halag Ágnes
}

\begin{abstract}
Absztrakt: Egy vidéki középvállalkozás szarvasmarhatelepének humán erőforrását vizsgáltam. Elöször a munkahelyi szervezettséget figyeltem meg. Adatokat gyüjtöttem a termelés tárgyi és humán tényezöire, elemeztem a munkatermelékenységi mutatókat. Megállapítottam, hogy a tehénállomány csökkentésével romlanak a munkatermelékenységi mutatók. Javaslom a tehénállomány növelését a munkatermelékenységi mutatók javitása érdekében.
\end{abstract}

Abstract: I examined the human resources of a cattle farm a medium-sized rural enterprise. First I observed the work organization. I collected data of production concerning material and human factors and I analysed the labour productivity indicators. I found that the labour productivity indicators deteriorate by reducing of the cow livestock. I propose to increase the livestock in order to improve the labour productivity indicators.

Kulcsszavak: emberi erőforrás, vidék, szarvasmarhatelep, munkatermelékenységi mutatók Keywords: human resources, rural, cattle farm, labour productivity indicators

\section{Bevezetés}

Napjainkban az embert a termelés legjelentősebb erőforrásának tekintjük, ugyanis az ember a termelés mozgatója. Az ember a tökével szemben a vállalkozás lelke. A munkaerő és a termelés felhasználás, a munkaidő kihasználás változása befolyásolja a termelési érték nagyságát is (Sabján-Sutus, 2009). Vizsgálatom célja, hogy megfigyeljem a munkaerö és termelési érték kapcsolatát egy vidéki szarvasmarhatelepen.

\subsection{Az ember a termelés mozgatója}

$\mathrm{Az}$ elmúlt évtizedekben a gazdasági és társadalmi átalakulások mentén minden termelő ágazat, így a mezőgazdaság is kereste a lehetőségeit a megváltozott körülmények között és igyekezett adottságait, meglévő erőforrásait kihasználni a hosszú távú versenyképesség fenntartása érdekében. Ebben a sokszor átláthatatlan és komplex piacgazdasági rendszerben a magyar mezögazdaság elvesztette azt a jelentőségét, amelyet hosszú időn keresztül, hagyományosan képviselt. A nemzetgazdaságban betöltött szerepe folyamatosan csökkent, és ezzel együtt elvesztette a foglalkoztatásban betöltött szerepét is.

A szarvasmarha tenyésztés mindig nagy szerepet töltött be a hazai mezőgazdaságban és a lakosság élelmiszerrel való ellátásában. További jelentősége többek között, hogy a növénytermesztés számára szolgáltatja a nélkülözhetetlen szervestrágyát, felhasználója a szálas takarmányoknak és üzemgazdasági szempontból a folyamatos termelésnek, árbevételnek köszönhetően pénzügyi stabilitást biztosít a mezőgazdasági üzemeknek. Üzemgazdasági szempontból pedig jellemzöje, hogy a többi állattenyésztési ágazathoz képest is nagy beruházást igényel (Zsótér-Túri, 2017) és a technológiai változtatásokkal kapcsolatosan kevésbé rugalmas. Az emberi erőforrások, amelyek a szarvasmarha telepeken a 
foglalkoztatott dolgozók mindennapi munkáján keresztül definiálódnak, nagymértékben képesek befolyásolni és variálni a többi erőforrás felhasználását, így hatékonyságát, és a termelés sikerességét, a gazdaság versenyképességét. A foglalkoztatottak munkához való viszonya számos tényezőtől függ, befolyásolják közgazdasági, pszichológiai és szociológiai elemek.

A szervezetek sosem működhettek az alapvető termelési tényezők és a közöttük számon tartott emberi erőforrások nélkül. $\mathrm{Az}$ emberek szervezeti versenyképességben betöltött szerepének felértékelödése azonban új jelentőseget ad kezelésüknek. Nemcsak a kutatók, hanem a gyakorlati szakemberek körében is egyre többen hangsúlyozzák, hogy az emberi erőforrásokhoz kapcsolódó tevékenységeket, döntéseket a költségtényező szerinti számbavétel helyett inkább befektetésként kell mérlegelni. A szervezet személyzetének menedzselése önálló és egyre nagyobb befolyást szerző szakmává vált. Mára sok nagy szervezetben nemcsak az üzleti stratégia megvalósításában, hanem annak alakítása során is várják a szakemberek értékteremtő hozzájárulását. Mellettük azonban a felső vezetés és a vezetôi hierarchia minden tagja fontos szerepet játszik az emberek menedzselésében. A funkció szakembereinek munkakörei, az őket foglalkoztató részleg szervezeti megoldásai mára éppoly sokrétủek, mint az egyes szervezetek által alkalmazott közelítések és megoldások (Karoliny, 2010).

\subsection{Szarvasmarha állomány alakulása Magyarországon}

Időszerủ a téma, mert a szarvasmarha állomány a rendszerváltás után csökkenő, al elmúlt években az állomány újra növekvő tendenciát mutat (1. ábra).

\section{1 ábra: Szarvasmarha állomány alakulása Magyarországon}

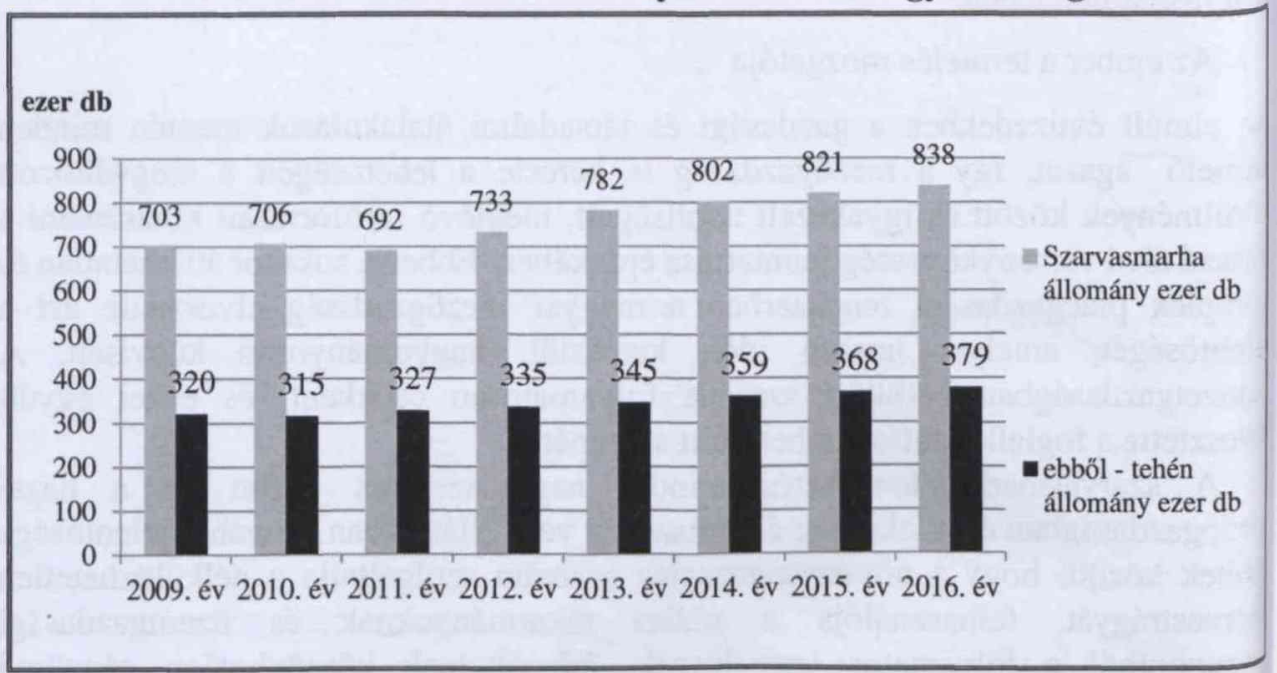

Forrás: saját szerkesztés (2017) 


\subsection{Emberi erőforrással kapcsolatos ismeretek}

A munkaerő-gazdálkodás fontos területe a létszámnagyságnak, a munkaerőfedezetnek a megállapítása. A munkaerő-fedezetnek egyensúlyban kell lenni a gazdasági tevékenység folytatásához nélkülözhetetlen munkaerő-szükséglettel. Első lépés a munkaerőigény előrejelzése. Az emberi erőforrás igényt a szervezet jövőbeli igényeinek kielégítéséhez szükséges dolgozói létszámként, ill. a szervezet szempontjából szükséges szakismerettel bíró munkaerő-összetételként lehet definiálni.

Az emberi munka valamennyi tevékenység első és legfontosabb erőforrása. A munkaerő, mint emberi erőforrás (humán erőforrás), annak a szellemi és fizikai munkavégző képességnek a hordozója, amellyel az ember a tárgyi, anyagi és természeti erőforrások felhasználásával megvalósítja a termelés (szolgáltatás) meghatározott gazdasági célú folyamatát. A munkaerő, mint humán erőforrás sajátos tulajdonsága, hogy cselekvéseit, és így tényleges teljesítményét a képességeitől, a diszpozíciótól (biológiai ritmus, elfáradás, közérzet), a motiváltságtól (ösztönzés, feladat iránti érdeklődés, szolidaritás), valamint a vele szemben támasztott követelményektől függően szabályozni képes (Magda, 2003).

\section{Anyag és módszer}

Statisztikai adatokon, elemzéseken alapuló módszerek. Ezek a módszerek azon a feltételezésen alapulnak, hogy a jövőbeli szituáció a múlttal a folyamatosság miatt valamilyen hasonlóságot mutat. Az adatgyüjtést interjúk segítségével, valamint módszeres megfigyeléssel végeztem. Az adatokat matematikai, statisztikai módszerek segítségével dolgoztam fel és táblázatokban foglaltam össze, melyeket diagramok segítségével ábrázoltam.

\section{Eredmények és értékelésük}

Megfigyeléseim során elsőként a munkahelyi szervezettséget figyeltem meg. A vizsgált Mezőhegyes környéki telepen (Zsótér, 2006) a teheneket kötetlen, mélyalmos, illetve pihenőboxos istállókban helyezték el, ez a kialakítási mód lehetővé teszi a munkahatékonyság növelését. Murphy is megállapította, hogy a termelőistállók kötetlen rendszerűvé alakítása után csökkent az élőmunka ráfordítás az általa vizsgált telepeken (Murphy, 1991). A tárgyi tényezők szintén meghatározóak a munkahelyi szervezettség szempontjából. Ennek megfelelően a vizsgált telepen $2 \times 8$ állásos Alfa Laval halszálkás fejőház található. A fejőházakban $2 \mathrm{db}$ tejhütő üzemel. A fejőberendezés tisztítását mosóautomata végzi. A takarmányozást traktorra függesztett takarmánykiosztó kocsi (TMR) segíti. A kitrágyázást traktoros tolólappal végzik naponta. A bealmozáskor traktorral viszik az istállókhoz a szalmabálát. A munkaidőt osztott műszakos beosztással oldják meg. A délelőtti munkaidő 5 óra, ilyenkor takarítanak, almoznak, a délutáni rövidebb, 3 órás, ilyenkor csak etetnek. Kivételt képez a fejős munkakör, ahol egyenlően oszlik el 4-4 órában. 


\subsection{Saját vizsgálatok}

A gazdaságok eredményességét javítja a pontos és naprakész számítógépes adatnyilvántartás. A telepen a RISKA telepnyilvántartó programot használják, amely minden - a szarvasmarha tartáshoz szükséges - termelési adatot rögzít.

Felmértem a telep munkaerỏ ellátottságát és a dolgozói létszám alakulását munkakörönként, melyet a következő táblázat tartalmaz (1. táblázat).

\section{1. táblázat: A dolgozói létszám alakulása a vizsgált telepen.}

\begin{tabular}{|c|c|c|}
\hline Munkakör megnevezése & 2015. év & 2016. év \\
\hline Takarmányos & $3 \mathrm{fö}$ & $3 \mathrm{fö}$ \\
\hline Nappali gondozó & $1 \mathrm{fö}$ & $1 \mathrm{fö}$ \\
\hline Fejös & $1 \mathrm{fö}$ & $1 \mathrm{fö}$ \\
\hline Éjjeli ör & $1 \mathrm{fö}$ & $1 \mathrm{fö}$ \\
\hline Felhajtó & $1 \mathrm{fö}$ & $1 \mathrm{fö}$ \\
\hline Váltós & $2 \mathrm{fö}$ & $2 \mathrm{fö}$ \\
\hline Összesen & $9 \mathrm{fö}$ & $9 \mathrm{fö}$ \\
\hline
\end{tabular}

Forrás: saját szerkesztés, üzemi adatok alapján (2017)

A fenti táblázatban látható a munkakörök alakulása között eltérés nem tapasztalható. Az éves átlagos állományi létszám sem változott az előző évhel képest.

\subsection{Munkatermelékenységi mutatók alakulása a vizsgált telepen}

Az alábbi táblázatból kiolvasható, hogy a vizsgált telepen a tehénállomány csökkent a dolgozói létszám változatlan maradt (2. táblázat).

\section{2. táblázat: A munkatermelékenységi mutatók alakulása a vizsgált telepen}

\begin{tabular}{|l|r|r|r|}
\hline \multicolumn{1}{|c|}{ MEGNEVEZÉS } & \multicolumn{1}{c|}{$2015 . e ́ v$} & \multicolumn{1}{c|}{ I016. év } & \multicolumn{1}{c|}{ Index \% } \\
\hline Átlagos tehén létszám (db) & 160 & 131 & $81,88 \%$ \\
\hline Fajlagos tejtermelés (liter/év/tehén) & 6922 & 7942 & $114,74 \%$ \\
\hline Éves tejtermelés (liter) & 1107579 & 1040456 & $93,94 \%$ \\
\hline Dolgozói létszám (fö) & 9 & 9 & $100,00 \%$ \\
\hline Dolgozóra jutó tehén (db/fö) & 17,7 & 14,5 & $81,92 \%$ \\
\hline Éves munkaóra (óra) & 21132 & 20230 & $95,73 \%$ \\
\hline 1 tehénre jutó munkaidö (óra/év) & 132,1 & 154,4 & $116,88 \%$ \\
\hline 100 liter tejtermelésre fordított munkaidő (óra) & 1,91 & 1,94 & $101,57 \%$ \\
\hline 1 dolgozóra jutó tejtermelés liter/fö/év & 123064 & 115606 & $93,94 \%$ \\
\hline
\end{tabular}

Forrás: saját szerkesztés, üzemi adatok alapján (2017)

Az éves tejtermelés 1107579 literről 1040456 literre csökkent, míg a tehé állomány $81,88 \%$-ra csökkent, addig az éves tejtermelés csak 93,94\%-ra, net egyenesen arányos, mert a fajlagos tejtermelés (egy tehénre eső tejtermelés) 114, \%-ra emelkedett. A dolgozói létszám nem változott az előző évhez képest, az éve munkaóra 95,73 \%-ra csökkent, de nem csökkent olyan arányban, mint a teh állomány változása, amely 81,88 \%-ra csökkent. Annak ellenére, hogy az ef tehénre jutó éves munkaóra 132,1 óráról 154,4 órára nött, a 100 liter tejtermelés 
fordított munkaidő 1,91 óráról, csupán 1,94 órára emelkedett, ami szintén több tényezőből tevődött össze, egyrészt nőtt a fajlagos tejtermelés, másrészt csökkent a tehénlétszám, csökkent a munkaóra, az azonos átlagos dolgozói létszám mellett.

\section{2. ábra: Főbb paraméterek összehasonlítása}

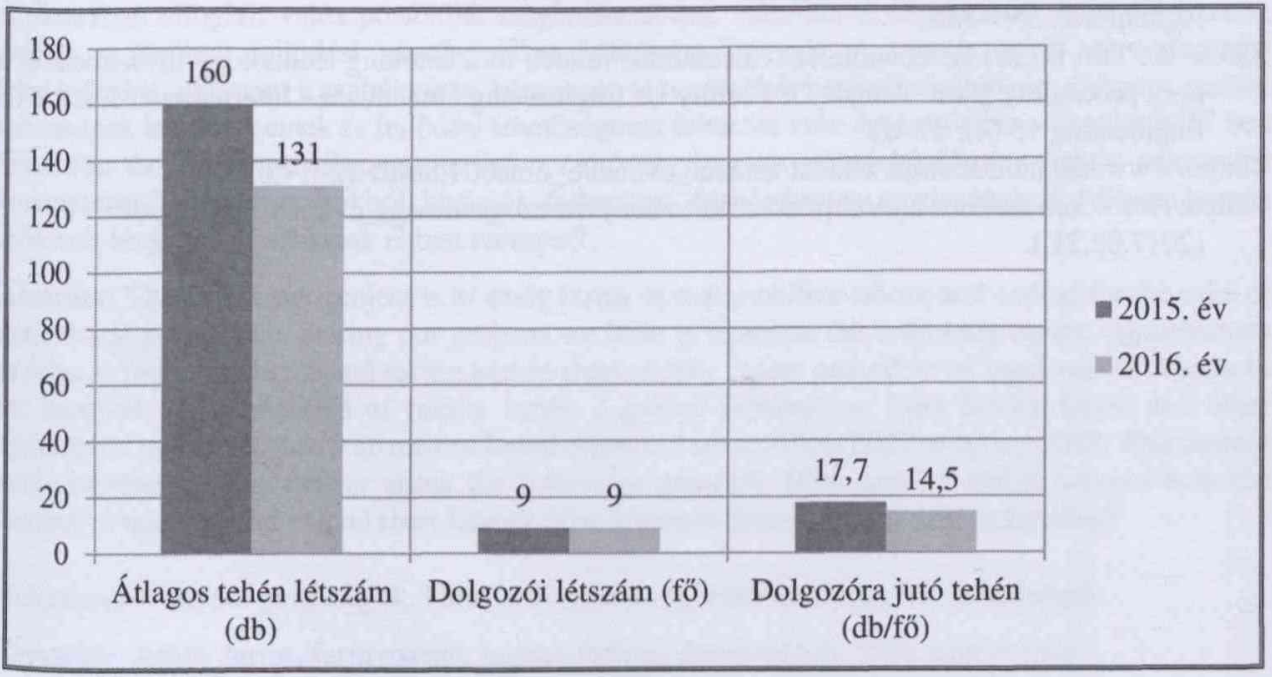

Forrás: saját szerkesztés, üzemi adatok alapján (2017)

A 2. ábra szemlélteti, hogy a tehén létszám változása, a dolgozói átlagos állományi létszám változatlan helyzete mellett az egy dolgozóra jutó tehén létszám csökkent, 17,7 db-ról 14,5 db-ra.

\section{Következtetések, záró gondolatok}

Egy hazai középvállalkozás tehenészeti telepén vizsgáltam a humán erőforrást. Megállapítottam, hogy a tehénállomány csökkentésével romlanak a munkatermelékenységi mutatók. Az átlagos állományi létszám mindkét vizsgált évben azonos, 9 fö, de az egy före eső tehénállomány csökkent, így csökkent az egy före eső tejtermelés is, pedig a fajlagos tejtermelés $15 \%$-kal nőt. Javaslom a tehénállomány növelését a munkatermelékenységi mutatók javítása érdekében. Érdemes lenne a jövőben vizsgálni a vállalkozás munkaerő állományának településre kifejtett társadalmi-, gazdasági hatásait (Zsótér-Császár, 2013).

\section{Irodalomjegyzék}

Karoliny Mné, Poór J (2010): Emberi erőforrás menedzsment kézikönyv. CompLex Kiadó, Budapest. Magda S. (2003): A mezőgazdasági vállalkozások gazdálkodásának alapjai. Mezógazdasági vállalkozások szervezése és ökonómiája I. Szaktudás Kiadó Ház, Budapest.

Murphy, N. (1991): Building for the future. Agriculture in Nothern Ireland. Belfast, 5-6.

Sabján J., Sutus I. (2009): A mezőgazdasági vállalkozások gazdálkodásának elemzése. Szaktudás Kiadó Ház, Budapest.

Zsótér B. (2006): Turizmus Mezőhegyesen: a Hotel Nonius bemutatása. In: Gál J. (szerk.): Európai Uniós Kutatási és Oktatási Projektek Napja és Leonardo da Vinci Learn at Work Projekt - 
találkozó [European Union Research and Educational Projects Day and Leonardo da Vinci Learn at Work Project Meeting]. Konferencia helye, ideje: Hódmezővásárhely, Magyarország̨ 2006.10.06 Hódmezővásárhely: Delfin Computer Informatikai Zrt., 2006. Paper CD. 6 p.

Zsótér B., Császár V. (2013): Examination of the socio-economic effects of a large food company in the South Hungarian plain on a given settlement. In: Ubreziová I, Horska E (szerk.): Modern Management in the $21^{\text {st }}$ Century: Theoretical and practical issues. Nitra: Slovak University of Agriculture, 359-385.

Zsótér B., Túri I. (2017): Economical calculations related to a smoking technology investment of a pork processing plant. Annals Of Faculty Of Engineering Hunedoara - International Journal of Engineering 15 (4): 57-61.

<http://www.ksh.hu/docs/hun/xstadat/xstadat_evkozi/e_oma001.html> (2017.03.16.)

<https://www.ksh.hu/docs/hun/xftp/idoszaki/evkonyv/mezogazdasagi_evkonyv_2014.pdf> (2017.02.21.) 